\title{
Cimetidine induces apoptosis of human salivary gland tumor cells
}

\author{
MASAKATSU FUKUDA ${ }^{1}$, SHIN TANAKA ${ }^{1}$, SEIJI SUZUKI ${ }^{1}$, KAORU KUSAMA ${ }^{2}$, \\ TADAYOSHI KANEKO $^{3}$ and HIDEAKI SAKASHITA ${ }^{1}$
}

\begin{abstract}
${ }^{1}$ Second Division of Oral and Maxillofacial Surgery, ${ }^{2}$ Division of Pathology, Department of Diagnostic and Therapeutic Sciences, Meikai University School of Dentistry, 1-1 Keyakidai, Sakado, Saitama 350-0283; ${ }^{3}$ Department of Oral and Maxillofacial Surgery, Tokyo Medical University, 6-1-1 Shinjuku, Shinjuku-ku, Tokyo 160-8402, Japan
\end{abstract}

Received September 5, 2006; Accepted November 22, 2006

\begin{abstract}
It has been reported that cimetidine, a histamine type-2 receptor (H2R) antagonist, inhibits the growth of glandular tumors such as colorectal cancer. However, its effects against salivary gland tumors are still unknown. We demonstrated previously that human salivary gland tumor (HSG) cells spontaneously express the neural cell adhesion molecule (NCAM) and also that HSG cell proliferation could be controlled via a homophilic (NCAM-NCAM) binding mechanism and that NCAM may be associated with perineural invasion by malignant salivary gland tumors. In the present study, we investigated the effects of cimetidine via the expression of NCAM on tumor growth and perineural/neural invasion in salivary gland tumor cells. Expression of both NCAM mRNA and protein was found to decrease in a dose-dependent manner upon treatment with cimetidine for $24 \mathrm{~h}$. The MTT assay and confocal laser microscopy clearly showed that HSG cells underwent apoptosis after treatment with cimetidine. Activation of caspases 3, 7, 8 and 9 was observed in HSG cells after cimetidine treatment, thus confirming that the apoptosis was induced by the activated caspases. Apaf-1 activity was also detected in HSG cells in a dose-dependent manner after treatment with cimetidine. We also found that the cimetidinemediated down-regulation of NCAM expression in HSG cells did not occur via blocking of the histamine receptor, even though H2R expression was observed on HSG cells, as two other H2R antagonists, famotidine and ranitidine, did not show similar effects. We demonstrated for the first time that cimetidine can induce significant apoptosis of salivary gland tumor cells, which express NCAM, at least in part by downregulation of NCAM expression on the cells. These findings
\end{abstract}

Correspondence to: Dr Masakatsu Fukuda, Second Division of Oral and Maxillofacial Surgery, Department of Diagnostic and Therapeutic Science, Meikai University School of Dentistry, 1-1 Keyakidai, Sakado, Saitama 350-0283, Japan

E-mail: fukudam@dent.meikai.ac.jp

Key words: neural cell adhesion molecule, human salivary gland tumor cell, cimetidine, adenoid cystic carcinomas, perineural invasion, apoptosis suggest that the growth, development and perineural/neural invasion of salivary gland tumor cells can be blocked by cimetidine administration through down-regulation of NCAM expression, as well as induction of apoptosis.

\section{Introduction}

Cimetidine is a histamine type-2 receptor (H2R) antagonist, commonly prescribed to treat gastro-esophageal reflux disease as well as gastric and duodenal ulcers (1). It has been reported that cimetidine improves the survival of patients with malignant tumors $(2,3)$, including gastric (4) and colorectal carcinomas (5). Since histamine has been shown to inhibit the growth of gastrointestinal cancers by several mechanisms including inhibition of cancer cell proliferation and enhancement of immune activity (3), cimetidine may act by enhancing the host immune response against tumor cells $(6,7)$ or by blocking the cell growth-promoting activity of histamine in colon cancer and melanoma cell lines (5,8-10). However, it is still unclear whether cimetidine blocks the development of salivary gland tumors.

Adenoid cystic carcinoma (ACC) is a well-known and typical malignant salivary gland tumor. ACCs are biologically aggressive and can metastasize many years after excision of the primary tumor. Facial palsy due to perineural/neural invasion is a particularly frequent and generally accepted hallmark of ACCs (11-13), and therefore blocking of perineural/neural invasion could be a strategy for arresting the development of ACC. We have demonstrated previously (14) that the neural cell adhesion molecule (NCAM) is expressed spontaneously in the human salivary gland tumor cell line HSG, derived from submandibular salivary gland, and that NCAM induces the adhesion of cancer cells expressing NCAM peptide to neural cells in vitro. We further found that HSG cell proliferation could be controlled via a homophilic (NCAM-NCAM) binding mechanism and that NCAM may be associated with perineural/neural invasion by malignant salivary gland tumors (15).

In the present study, we examined the effects of cimetidine via the expression of NCAM on tumor growth and perineural/neural invasion in salivary gland tumor, in vitro. We demonstrated that cimetidine can induce apoptosis of HSG 
cells, which express NCAM, at least in part by down-regulation of NCAM expression on the cells.

\section{Materials and methods}

Reagents. Mouse anti-human NCAM monoclonal antibodies for the 120- and 140-kDa isoforms, and for 180-kDa isoform (MAb NCAM antibody; CD56) were purchased from Santa Cruz Biotechnology and Becton-Dickinson (BD) Biosciences (CA, USA), respectively. Rabbit anti-human apoptotic protease-activating factor-1 (apaf-1) polyclonal antibody was also purchased from BD Biosciences. MAb $\beta$-actin and MTT [3-(4,5-dimethylthiazol-2-yl)-2,5-diphenyl tetrazolium bromide] were obtained from Sigma (MI, USA). The biotinylated horse anti-mouse $\operatorname{IgG}(\mathrm{H}+\mathrm{L})$ antibody and Streptavidin-peroxidase were obtained from Vector Laboratories (Burlingame, CA) and Gibco-BRL, Life Technologies (MD, USA), respectively. Mouse anti-human caspase-7 and -8 monoclonal antibodies and rhNCAM peptide were purchased from Santa Cruz Biotechnology, and caspase-3 and -9 were purchased from Medical and Biological Laboratories. For the detection of H2R by immunoblot analysis, rabbit anti-human $\mathrm{H} 2 \mathrm{R}$ polyclonal antibody was purchased from Chemicon International (Temecula, CA). Cimetidine, famotidine, and ranitidine were purchased from Sigma Chemical Co. H2R blockers were dissolved in PBS.

Cell culture. The HSG cell line, derived from a human submandibular salivary gland, was established by Shirasuna et al (16) and three human oral squamous cell carcinoma (HOSCC) cell lines, HSC-2 and -3 and $\mathrm{Ca} 9-22$ obtained from the American Type Culture Collection (ATCC, VA, USA) were respectively maintained in RPMI-1640 medium supplemented with $10 \%$ heat-inactivated fetal bovine serum (FBS), $100 \mathrm{IU} / \mathrm{ml}$ penicillin and $100 \mu \mathrm{g} / \mathrm{ml}$ streptomycin, and grown to confluence in $25-\mathrm{cm}^{2}$ culture flasks at $37^{\circ} \mathrm{C}$ in a humidified $5 \%$ $\mathrm{CO}_{2}$ incubator until use.

RNA extraction, Northern blot analysis and RT-PCR. Total RNA was extracted from HSG cells by the acid-guanidiniumphenol-chloroform (AGPC) method (17). Briefly, HSG monolayers were scraped off and dissolved in solution D (4 M guanidinium thiocyanate solution containing $25 \mathrm{mM}$ sodium citrate, $0.5 \%$ sarcosyl, and $0.1 \mathrm{M}$ 2-mercaptoethanol), then extracted with phenol-chloroform and chloroform. The RNA was alcohol-precipitated and the pellet was dissolved in sterile water. Total RNA $(10 \mu \mathrm{g})$ was separated by electrophoresis on a $1 \%$ formaldehyde-agarose gel. The RNA was transferred to Hybond-N nylon membranes (Amersham Pharmacia Biotech, Buckinghamshire, UK), and the filter was cross-linked by using a UV-cross linker (Stratagene, La Jolla, CA, USA), then pre-hybridized with salmon-sperm DNA $(0.15 \mathrm{mg} / \mathrm{ml})$ for $4 \mathrm{~h}$ at $42^{\circ} \mathrm{C}$. Blots were hybridized with a human NCAM cDNA probe according to the method reported previously (15).

Random hexamer-primed single-stranded cDNA was synthesized with an RNA LA PCR ${ }^{\mathrm{TM}}$ kit (Takara Shuzo) from $1.0 \mu \mathrm{g}$ of total RNA in a final volume of $20 \mu \mathrm{l}$ with 0.25 units of avian myeloblastosis virus reverse transcriptase at $42^{\circ} \mathrm{C}$
Table I. The primer sequences used in this study.

\begin{tabular}{cc}
\hline Oligonucleotides & Sequence \\
\hline H2R primer pairs & \\
Forward primer & 5'-TTCATCGTGTCCTTGGCTATC-3' \\
Reverse primer & 5'-CTGAGAGGCGTTGGACCTC-3' \\
3-actin primer pairs & \\
Forward primer & 5'-GTGGGGCGCCCCAGGCACCA-3' \\
Reverse primer & 5'-CTCCTTAATGTCACGCACGATTTC-3' \\
\hline
\end{tabular}

for $60 \mathrm{~min}$. An aliquot $(1.0 \mu \mathrm{l})$ of the reaction mixture was diluted with $10 \mu \mathrm{l}$ of PCR buffer containing 4 pmole each of $5^{\prime}$ and $3^{\prime} \mathrm{H} 2 \mathrm{R}$ primer sets was previously designated by Jutel et al (18) and $B$-actin primer sets (Table I). The PCR reaction was then performed with 2.5 units of Takara LA $\mathrm{Taq}^{\mathrm{TM}}$ (Takara Shuzo). The samples were subjected to denaturation at $94^{\circ} \mathrm{C}$ for $2 \mathrm{~min}$. This was followed by 35 cycles of denaturation at $94^{\circ} \mathrm{C}$ for $30 \mathrm{sec}$, annealing at $62^{\circ} \mathrm{C}$ for $30 \mathrm{sec}$, and extension at $68^{\circ} \mathrm{C}$ for $50 \mathrm{sec}$. The last cycle had an extension period of $7 \mathrm{~min}$. The amplified DNA was electrophoresed on a $2.0 \%$ agarose gel, stained with ethidium bromide and visualized on a UV illuminator, then photographed.

Western blot analysis. For Western blot analysis, total cell extracts prepared from each cell line were analyzed with the appropriately diluted antibody according to the method reported previously (15).

Induction of apoptosis by cimetidine (MTT assay). Near confluent cells $\left(5 \times 10^{4}\right.$ cells $\left./ \mathrm{ml}\right)$ were incubated for $24 \mathrm{~h}$ on a 96-microwell plate (Nalge Nunc). The cells were washed once with PBS and incubated with various concentrations of cimetidine $\left(10^{-10}-10^{-2} \mathrm{M}\right)$ for $24 \mathrm{~h}$ in RPMI-1640 medium with $10 \%$ FBS. The cells were washed once with PBS and incubated with $0.2 \mathrm{mg} / \mathrm{ml} \mathrm{MTT}$ for $4 \mathrm{~h}$. After removing the medium, cells were lysed with $100 \mu \mathrm{l}$ of DMSO, and the relative viable cell number was determined by measuring absorbance of the cell lysate at $540 \mathrm{~nm}$.

Morphological observation of apoptotic cells. HSG cells $\left(1 \times 10^{4}\right.$ cells $\left./ \mathrm{ml}\right)$ were maintained with RPMI-1640 supplemented on a $10 \mathrm{~cm}^{2}$ glass plate (Iwaki, Chiba, Japan). The cells were washed once with PBS and incubated $10^{-4} \mathrm{M}$ of cimetidine for $24 \mathrm{~h}$ in RPMI-1640 medium with $10 \% \mathrm{FBS}$. The apoptotic cells were directly observed under a confocal laser microscope.

\section{Results}

Detection of NCAM mRNA in HSG cells after treatment with cimetidine. To examine how cimetidine affects to the expression of NCAM, HSG cells were treated with various doses of cimetidine $\left(10^{-8}-10^{-2} \mathrm{M}\right)$ for $24 \mathrm{~h}$. Total RNA extracts from HSG cells were subjected to Northern blot analysis to determine the quantity of NCAM mRNA expressed in HSG cells. A single band of $\sim 5.0 \mathrm{~kb}$ was found migrating above 


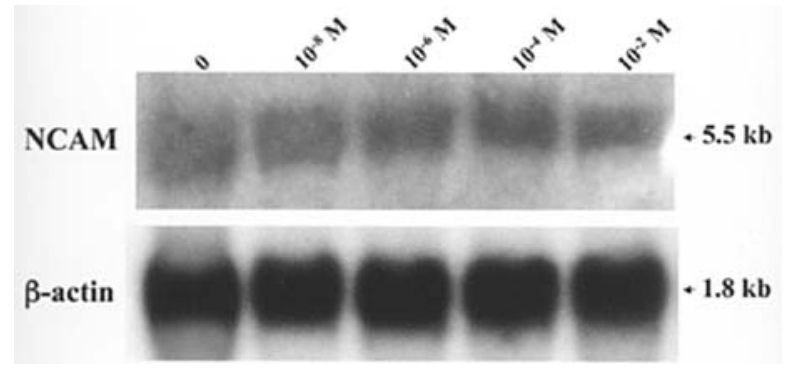

Figure 1. Northern blot analysis of NCAM mRNA extracted from HSG cells treated with various doses of cimetidine $\left(10^{-8}-10^{-2} \mathrm{M}\right)$ for $24 \mathrm{~h}$. The levels of NCAM mRNA expression at $5.0 \mathrm{~kb}$ gradually decreased in a dosedependent manner. As an internal control, detection of B-actin mRNA was performed using a $B$-actin cDNA probe, revealing that the obtained total RNA was intact.

the $28 \mathrm{~S}$ ribosomal band. Thereafter, the level of NCAM mRNA expression decreased gradually upon treatment with cimetidine for $24 \mathrm{~h}$ in a dose-dependent manner (Fig. 1). As an internal control, $B$-actin mRNA was monitored to assess the integrity of the total RNA extracted from the HSG cells, and this demonstrated that the total RNA obtained was intact.

Expression of NCAM protein in HSG cells after cimetidine treatment. SDS-solubilized cell extracts of HSG cells treated with various doses of cimetidine for $24 \mathrm{~h}$, as described above, were subjected to Western blot analysis to determine the quantity of NCAM protein expressed in the cells. It was revealed that the concentration of NCAM peptide induced in HSG cells decreased gradually and dose-dependently after treatment with cimetidine for $24 \mathrm{~h}$ (Fig. 2).

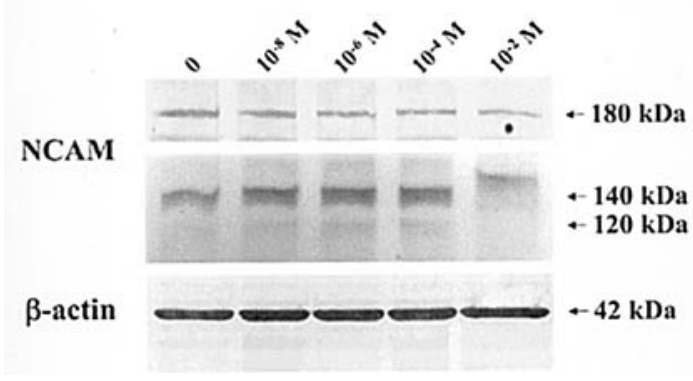

Figure 2. Western blot analysis of NCAM peptides extracted from HSG cells treated with various doses of cimetidine $\left(10^{-8}-10^{-2} \mathrm{M}\right)$ for $24 \mathrm{~h}$. The NCAM peptides induced in the HSG cells were the 120, 140 and $180 \mathrm{kDa}$ isoforms, which gradually decreased in a dose-dependent manner after treatment with cimetidine for $24 \mathrm{~h}$.

MTT assay. To confirm the viability of HSG cells after treatment with various doses of cimetidine for $24 \mathrm{~h}$, MTT assay was performed. The MTT assay showed a significant and dose-dependent reduction in the number of HSG cells upon treatment with cimetidine for $24 \mathrm{~h}$ (Fig. 3A). Moreover, to confirm whether cimetidine affected HSG cells specifically, we also treated three HOSCC cell lines, HSC-2, -3 and Ca9-22, for $24 \mathrm{~h}$ with the same doses of cimetidine, and MTT assays were carried out. It was found that the HOSCC cell lines were almost completely resistant to cimetidine-induced apoptosis (Fig. 3B). These results suggested that HSG cells, which express NCAM, might be induced to undergo apoptosis by treatment with cimetidine.

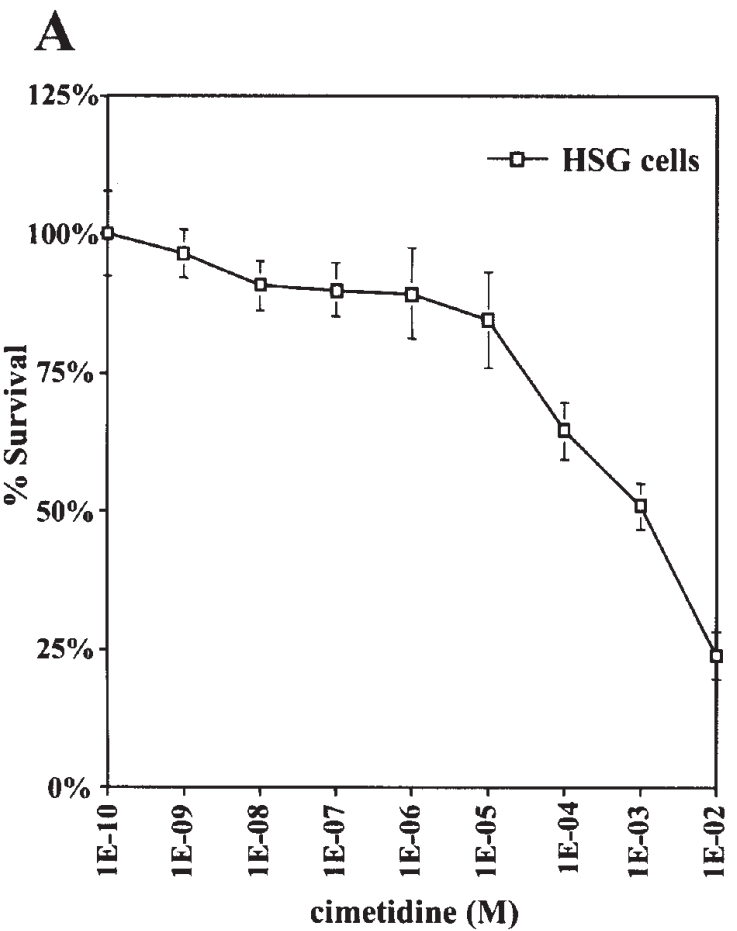

\section{B}

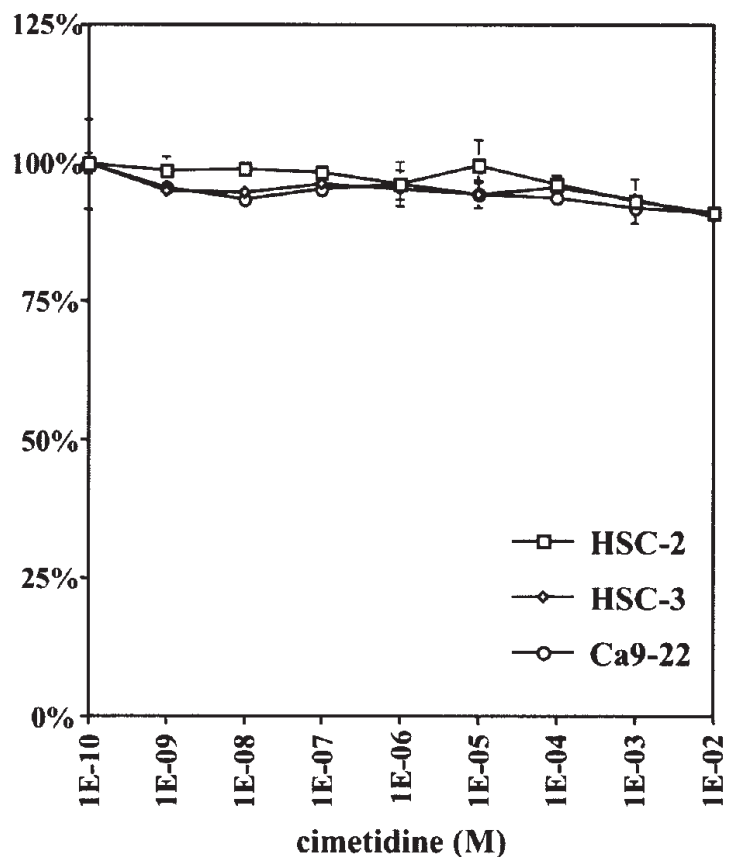

Figure 3. MTT assay. Dose-response survival curves based on the MTT assay were generated for HSG cells treated with different concentrations of cimetidine $\left(10^{-10}-10^{-2} \mathrm{M}\right)$ for $24 \mathrm{~h}$. There was a significant and dose-dependent reduction in the number of HSG cells (A). However, HSC-2, HSC-3, and Ca9-22 cells (B) were almost completely resistant to cimetidine-induced apoptosis ( $n=3$ experiments; means \pm SD). 

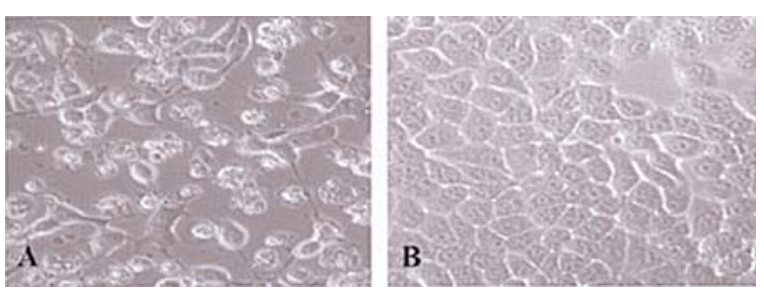

Figure 4. Confocal laser microscopy. Apoptosis induced with $10^{-4} \mathrm{M}$ cimetidine for $24 \mathrm{~h}$ was directly observed as blebbing of the cellular membrane, shrinkage of the cytoplasm and release of apoptotic vesicles on HSG cells under a confocal laser microscope (original magnification, x40) (A). No apoptosis was observed on the surfaces of control HSG cells without cimetidine treatment (original magnification, $\mathrm{x} 40$ ) (B).

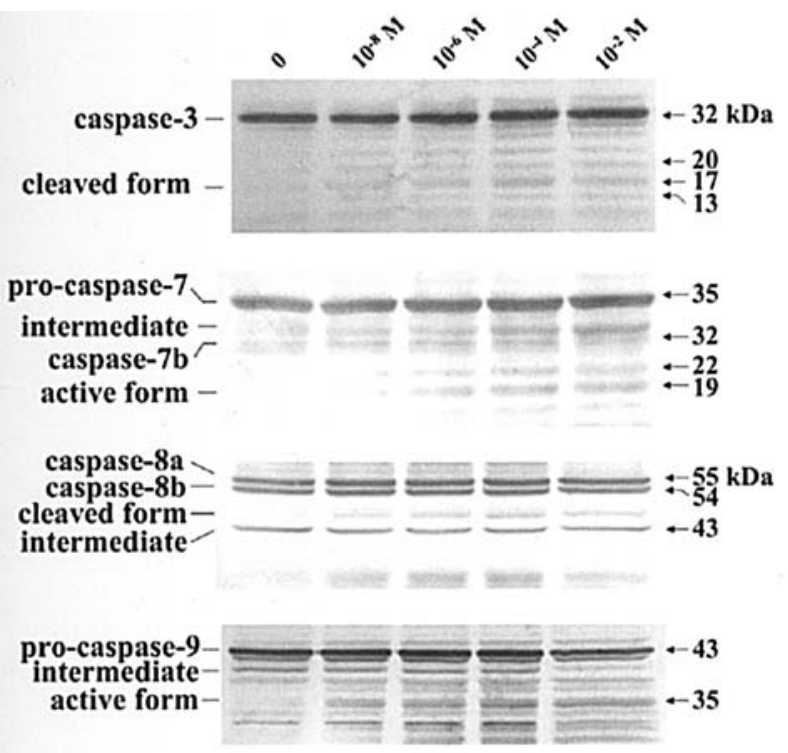

Figure 5. Western blot analysis of activated caspase extracted from HSG cells treated with various doses of cimetidine $\left(10^{-8}-10^{-2} \mathrm{M}\right)$ for $24 \mathrm{~h}$. Cleavage product formation mediated by activated caspases $3,7,8$ and 9 was observed, and this increased in a dose-dependent manner after treatment with cimetidine.

Induction of apoptosis in HSG cells. Since the process of apoptosis rapidly induces dramatic effects on cellular structure, the effects of cimetidine on HSG cells were visualized by confocal laser microscopy. HSG cells were treated with or without $10^{-4} \mathrm{M}$ cimetidine for $24 \mathrm{~h}$, then imaged by confocal laser microscopy (Fig. 4A and B). The results indicated that cimetidine induced HSG cell death characterized by various hallmarks of apoptosis, including cellular membrane blebbing, cytoplasm shrinkage and the release of apoptotic vesicles.

Detection of activated caspases in HSG cells after cimetidine treatment. Regardless of circumstance, the induction and execution of apoptotic events require the activation of caspases, a family of aspartate-specific cysteine proteinases. To investigate how the apoptotic machinery is regulated by cimetidine in HSG cells, Western blot analysis was carried out using antibodies for individual caspases. Activated caspases 3, 7, 8 and 9 were observed in HSG cells after treatment with cimetidine (Fig. 5), thus confirming that activated caspase

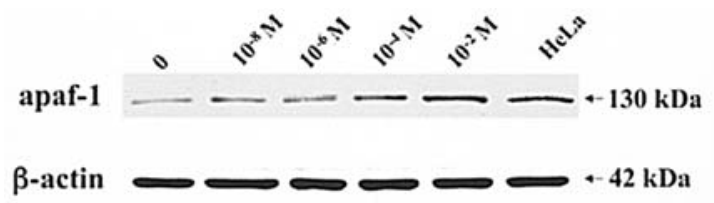

Figure 6. Western blot analysis of apaf-1 protein extracted from HSG cells treated with various doses of cimetidine $\left(10^{-8}-10^{-2} \mathrm{M}\right)$ for $24 \mathrm{~h}$. Apaf-1 was constitutively expressed in HSG cells, and the concentrations were clearly increased by cimetidine in a dose-dependent manner. As a positive control, apaf-1 protein detection in HeLa cells was performed.
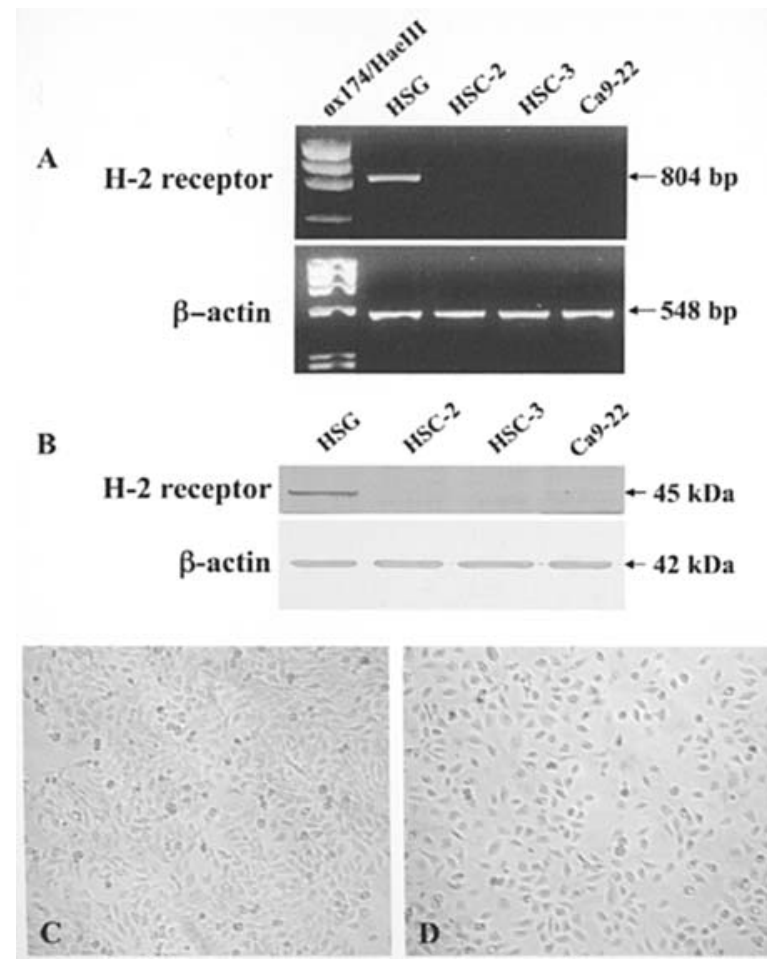

Figure 7. RT-PCR and Western blot analysis of H2R mRNA and protein extracted from HSG and HOSCC cells. Both H2R mRNA (A) and protein (B) were detected only in HSG cells. Then, HSG cells were treated with two other H2R antagonists, famotidine and ranitidine, at $10^{-4} \mathrm{M}$ for $24 \mathrm{~h}$. Neither famotidine (C) nor ranitidine (D) induced apoptosis of HSG cells.

mediates apoptosis in the HSG cells upon stimulation with cimetidine.

Apaf-1 activity. To examine whether this pathway of apoptotic signals involves the DNA-damage or death receptor pathway, we evaluated the expression of apaf- 1 in HSG cells after treatment with cimetidine. Apaf-1 was constitutively expressed in HSG cells, and the concentrations were clearly increased by cimetidine in a dose-dependent manner (Fig. 6). This result indicated that cimetidine induces apoptosis of HSG cells via the DNA-damage signal through the mitochondria.

Involvement of $\mathrm{H} 2 \mathrm{R}$ in apoptosis. To confirm whether $\mathrm{H} 2 \mathrm{R}$ is expressed in HSG and HOSCC cells, RT-PCR and Western blot analysis were carried out. Both $\mathrm{H} 2 \mathrm{R}$ mRNA and protein were detected only in HSG cells (Fig. 7A and B). These results suggest that cimetidine induces apoptosis of HSG cells via 
the H2R. Then, HSG cells were treated with two other H2R antagonists, famotidine and ranitidine, at $10^{-4} \mathrm{M}$ for $24 \mathrm{~h}$. Neither famotidine nor ranitidine induced apoptosis of HSG cells (Fig. 7C and D), indicating that this action of cimetidine is probably not mediated via the $\mathrm{H} 2 \mathrm{R}$.

\section{Discussion}

Cimetidine, the most studied H2R antagonist, has been demonstrated to possess anti-tumor activity against colon, gastric and kidney cancers, and melanomas (5,8-10). According to a recent study by Lefranc et al (19), this activity involves a number of different mechanisms of action, characterized by three overall characteristics: a) a direct inhibitory effect on tumor growth by blocking the cell growth-promoting activity of histamine via activation of $\mathrm{H} 2$ receptors, and an indirect effect involving inhibition of tumor-associated angiogenesis; b) an immunomodulatory effect through enhancement of the host's immune response to tumor cells; c) an inhibitory effect on cancer cell migration and adhesion to endothelial cells, thus inhibiting tumor neo-angiogenesis and metastasis development. In this study, we investigated the effect of cimetidine via the expression of NCAM on tumor growth and perineural/neural invasion in salivary gland tumor using an in vitro cell culture system. These experiments clearly demonstrated that cimetidine effectively induced apoptosis of HSG cells by preventing the induction of NCAM.

NCAM is a membrane glycoprotein receptor of the immunoglobulin supergene family that mediates cell-to-cell adhesion via homophilic binding (NCAM to NCAM) and cell-to-substrate adhesion via heterophilic binding (NCAM binding to another ligand or counter-receptor) (20). NCAM is recognized to play an important role in perineural invasion in various neoplasms, such as bile duct cancer, gallbladder carcinoma, melanoma and adenoid cystic carcinoma of the head and neck (11-13,21-23). Previously, we also demonstrated by immunohistochemical methods that adenoid cystic carcinoma of the parotid gland is distinctly positive for NCAM (14). Moreover, we found that HSG cell proliferation could be controlled via a homophilic (NCAM-NCAM) binding mechanism and that NCAM may be associated with perineural/ neural invasion by malignant salivary gland tumors (15).

However, it is unknown how NCAM-expressing cells such as HSG behave when exposed to cimetidine. In the present study, therefore, we treated HSG cells with cimetidine in vitro, and found that the levels of NCAM mRNA and protein decreased in a dose-dependent manner after treatment with cimetidine for $24 \mathrm{~h}$. Data from Western blot analysis revealed that lysates from HSG cells underwent a change similar to degradation at a cimetidine concentration of $10^{-2} \mathrm{M}$. MTT assay was then performed to examine the viability of HSG cells treated with cimetidine, and the data suggested that the HSG cells underwent apoptosis.

Apoptosis is an active process of cell death characterized by cytoplasmic shrinkage, membrane blebbing, nuclear fragmentation and internucleosomal DNA cleavage. Disruption of apoptosis and cell proliferation are key events in tumorigenesis. To investigate the appearance of HSG cells undergoing apoptosis, confocal laser microscopy and detection of activated caspases were respectively carried out, and the findings confirmed that HSG cells obviously underwent apoptosis upon treatment with cimetidine. From analysis of apaf- 1 activity, we further found that cimetidine induced apoptosis of HSG cells via the DNA-damage signal through the mitochondria, inducing release of cytochrome $c$ to the cytoplasm. However, cimetidine had no effect on HOSCC cell lines, which do not express NCAM. These results imply that the effect of cimetidine is specific to NCAM-expressing tumor cells, such as HSG cells; furthermore, blocking the activity of NCAM through cimetidine, as well as the homophilic (NCAMNCAM) binding mechanism, rather than regulating a signaling pathway of cell proliferation, may in fact induce a negative signal such as apoptosis in HSG cells. In addition, homophilic (NCAM-NCAM) binding may activate multiple signaling pathways that differ among cell types. Simultaneously, it was confirmed whether H2R is expressed in HSG and HOSCC cells, as cimetidine is an $\mathrm{H} 2 \mathrm{R}$ antagonist. Both $\mathrm{H} 2 \mathrm{R}$ mRNA and protein were detected only in HSG cells, thus suggesting that cimetidine induces apoptosis of HSG cells via the H2R. However, neither famotidine nor ranitidine, two other H2R antagonists, induced apoptosis of HSG cells. This observation indicated that the cimetidine-mediated down-regulation of NCAM expression, as well as induction of apoptosis in HSG cells, did not occur via blocking of the histamine receptor. It has been reported that NCAM expression is regulated by $\mathrm{NF}-\kappa \mathrm{B}(24)$, and that NF- $\mathrm{BB}$ activity is induced by NCAM (25); in other words, homophilic NCAM binding can increase $\mathrm{NF}-\kappa \mathrm{B}$ activity, then NF- $\mathrm{BB}$ regulates NCAM expression. Some studies have also indicated that cimetidine may have antioxidant activity (26-28), and antioxidants have been shown to block the NF- $\mathrm{KB}$ activation cascade (29). If cimetidine inhibits NF- $\mathrm{\kappa B}$ activation, the expression of NCAM would be down-regulated, and consequently HSG cell proliferation, which requires homophilic NCAM binding, would be blocked. Therefore, the exact mechanisms by which cimetidine suppresses development of cancers, including the regulation of NF- $\mathrm{KB}$ activation, remain to be elucidated.

The present findings suggest that the growth, development and perineural/neural invasion of salivary gland tumor cells can be blocked by cimetidine administration through downregulation of NCAM expression, as well as induction of apoptosis. Although malignant glandular tumors are known to be generally resistant to radiation therapy and chemotherapy, the clinical application of cimetidine as an anti-cancer drug might be a useful approach for devising future therapeutic strategies against NCAM-expressing tumors such as adenoid cystic carcinoma. Further studies will be required to identify the signal transduction pathway utilized by glandular tumors after treatment with cimetidine and to establish a strategy for cimetidine-based salivary gland tumor therapy.

\section{References}

1. Freston JW: Cimetidine I. Developments, pharmacology, and efficacy. Ann Intern Med 97: 573-580, 1982.

2. Burtin C, Noirot C, Scheinmann P, Galoppin L, Sabolovic D and Bernard P: Clinical improvement in advanced cancer disease after treatment combining histamine and $\mathrm{H} 2$-antihistaminics (ranitidine or cimetidine). Eur J Cancer Clin Oncol 24: 161-167, 1988.

3. Siegers CP, Andresen S and Keogh JP: Does cimetidine improve prospects for cancer patients? A reappraisal of the evidence to date. Digestion 60: 415-421, 1999. 
4. Tonnesen H, Knigge U, Bulow S, et al: Effect of cimetidine on survival after gastric cancer. Lancet 2: 990-992, 1988.

5. Adams WJ, Lawson JA and Morris DL: Cimetidine inhibits in vivo growth of human colon cancer and reverses histamine stimulated in vitro and in vivo growth. Gut 35: 1632-1636, 1994.

6. Hansbrough JF, Zapata-Sirvent RL and Bender EM: Prevention of alterations in postoperative lymphocyte subpopulations by cimetidine and ibuprofen. Am J Surg 151: 249-255, 1986.

7. Adams WJ, Morris DL, Ross WR, Lubowski DZ and King DW: Cimetidine preserves non-specific immune function after colonic resection for cancer. Aust N Z J Surg 64: 847-852, 1994.

8. Sasson AR, Gamagami R, An Z, Wang X, Moossa AR and Hoffman RM: Cimetidine: an inhibitor or promoter of tumor growth? Int J Cancer 81: 835-838, 1999.

9. Lawson JA, Adams WJ and Morris DL: Ranitidine and cimetidine differ in their in vitro and in vivo effects on human colonic cancer growth. Br J Cancer 73: 872-876, 1996.

10. Reynolds JL, Akhter J and Morris DL: In vitro effect of histamine and histamine $\mathrm{HI}$ and $\mathrm{H} 2$ receptor antagonists on cellular proliferation of human malignant melanoma cell lines. Melanoma Res 6: 95-99, 1996.

11. Gandour-Edwards R, Kapadia SB, Barnes L, Donald PJ and Janecka IP: Neural cell adhesion molecule in adenoid cystic carcinoma invading the skull base. Otolaryngol Head Neck Surg 117: 453-458, 1997.

12. Hutcheson JA, Vural E, Korourian S and Hanna E: Neural cell adhesion molecule expression in adenoid cystic carcinoma of the head and neck. Laryngoscope 110: 946-948, 2000.

13. França CM, Jaeger MM, Jaeger RG and Araujo NS: The role of basement membrane proteins on the expression of neural cell adhesion molecule (N-CAM) in an adenoid cystic carcinoma cell line. Oral Oncol 36: 248-252, 2000.

14. Fukuda M, Tanaka A, Hamao A, et al: Expression of neural cell adhesion molecule (NCAM) in human salivary gland tumor (HSG) cells. Hosp Dent (Tokyo) 13: 109-113, 2001.

15. Fukuda M, Horiuchi Y, Oku Y, et al: Induction of apoptosis in human salivary gland tumor cells by anti-NCAM antibody. Oncol Rep 14: 1143-1149, 2005.

16. Shirasuna K, Sato M and Miyazaki T: A neoplastic epithelial duct cell line established from an irradiated human salivary gland. Cancer 48: 745-752, 1981.
17. Chomczynski P and Sacchi N: Single-step method of RNA isolation by acid guanidinium thiocyanate-phenol-chloroform extraction. Anal Biochem 162: 156-159, 1987.

18. Jutel M, Watanabe T, Klunker S, et al: Histamine regulates T-cell and antibody responses by differential expression of $\mathrm{H} 1$ and $\mathrm{H} 2$ receptors. Nature 413: 420-425, 2001.

19. Lefranc F, Yeaton P, Brotchi J and Kiss R: Cimetidine, an unexpected anti-tumor agent, and its potential for the treatment of glioblastoma. Int J Oncol 28: 1021-1030, 2006.

20. Edelman GM and Crossin KL: Cell adhesion molecules: implications for a molecular histology. Annu Rev Biochem 60: 155-190, 1991.

21. Seki H, Koyama K, Tanaka J, Sato Y and Umezawa A: Neural cell adhesion molecule and perineural invasion in gallbladder cancer. J Surg Oncol 58: 97-100, 1995.

22. Seki H, Tanaka J, Sato Y, Kato Y, Umezawa A and Koyama K: Neural cell adhesion molecule (NCAM) and perineural invasion in bile duct cancer. J Surg Oncol 53: 78-83, 1993.

23. Mooy CM, Luyten GP, de Jong PT, Jensen OA, Luider TM, van der Ham F and Bosman FT: Neural cell adhesion molecule distribution in primary and metastatic uveal melanoma. Hum Pathol 26: 1185-1190, 1995.

24. Simpson CS and Morris BJ: Regulation of neuronal cell adhesion molecule expression by NF-kappa B. J Biol Chem 275: 16879-16884, 2000

25. Krushel LA, Cunningham BA, Edelman GM and Crossin KL: NF-kappaB activity is induced by neural cell adhesion molecule binding to neurons and astrocytes. J Biol Chem 274: 2432-2439, 1999.

26. Kimura E, Koike T, Shimizu Y and Kodama M: Complexes of the histamine $\mathrm{H} 2$-antagonist cimetidine with divalent and monovalent copper ions. Inorg Chem 25: 2242-2246, 1986.

27. Uchida $\mathrm{K}$ and Kawakishi S: Cimetidine anti-ulcer drug as a powerful hydroxyl radical scavenger. Agric Biol Chem 54: 2485-2487, 1990.

28. Lapenna D, De Gioia S, Mezzetti A, Grossi L, Festi D, Marzio L and Cuccurullo F: H2-receptor antagonists are scavengers of oxygen radicals. Eur J Clin Invest 24: 476-481, 1994

29. Tozawa K, Sakurada S, Kohri K and Okamoto T: Effects of anti-nuclear factor $\mathrm{kB}$ reagents in blocking adhesion of human cancer cells to vascular endothelial cells. Cancer Res 55: 4162-4167, 1995. 